\title{
500 million years of charted territory: functional ecological traits in bryophytes
}

\author{
DANIEL E. STANTON ${ }^{1} \&$ KIRSTEN K. COE $^{2}$ \\ ${ }^{1}$ Dept. of Ecology, Evolution and Behavior, University of Minnesota, Saint Paul, MN 55108, USA. \\ ”stan0477@umn.edu, ○ https://orcid.org/0000-0002-6713-9328 \\ ${ }^{2}$ Department of Biology, Middlebury College, Middlebury, VT, 05753, USA. \\ "coe@middlebury.edu; ○ https://orcid.org/0000-0002-1560-8022
}

\begin{abstract}
Since the late Cambrian era, bryophytes have been shaping terrestrial ecosystems through unique and diverse suites of anatomical, physiological, and morphological traits. In this review we highlight historical and recent work in bryophyte functional ecology, with an emphasis on knowledge gaps and opportunities for future work. While we cannot always avoid the temptation to contrast with tracheophyte (especially angiosperm) studies, our aim is to de-center that perspective in favor of a more universal understanding of functional land plant ecology. We therefore center our description on three core aspects of bryophytes that are poorly represented in tracheophyte studies: (I) dynamic water content (including poikilohydry and desiccation tolerance), (II) multiple scales of interaction with environment, and (III) reproduction and life history. We also highlight the diverse and wide-ranging influence bryophytes have on ecosystem processes, including primary productivity, nutrient cycling, hydrology, and ecological interactions with other species. Furthermore, while the study of bryophyte functional traits has rapidly grown in the past decade, important gaps in phylogenetic and geographic coverage persist and constrain the development of a more universal land plant functional ecology theory.
\end{abstract}

Keywords: Ecosystem processes, effect traits, land plants, liverwort, moss, poikilohydry, response traits

\section{What are functional traits and why are they important to study in bryophytes?}

Functional ecology seeks to provide mechanistic understanding of the interactions between organisms and their environment. In this regard the remarkable diversity of bryophyte species represents a challenge: a detailed, traditional species-by-species understanding would be impossibly time-consuming for dozens, let alone thousands of species (not to mention plasticity within species and even genotypes). Instead, we seek generalizations that allow us to bridge across taxonomic diversity by emphasizing shared processes. This concept is hardly new, but has gained considerable momentum in recent years with the focus on "functional traits". These are traits that characterize an interaction with the environment, either directly or indirectly (Lavorel \& Garnier 2002). Historically, functional traits have been divided into response traits (those that allow for growth and reproduction in individual organisms) and effect traits (those that directly affect processes at the community or ecosystem scale; Lavorel \& Garnier 2002), with the obvious potential that some traits can act in both categories (see Fig. 1). To illustrate, metrics of chlorophyll fluorescence (a response trait) are indicative of photosynthetic capacity at the individual or leaf level, while aboveground net primary productivity (NPP; an effect trait) directly influences ecosystem processes. On the other hand, carbon dioxide fixation rate represents a response-effect (R-E) trait as it spans processes influencing individual performance and survival as well as ecosystem productivity.

Functional traits do not represent independent features of an organism. They operate as correlated suites of traits, constrained by trade-offs. One of the most important conceptual advances in modern functional ecology was the "investment" analogy. This approach, perhaps best known from the Leaf Economic Spectrum (Wright et al. 2004) for embryophytes but also applied to a wide range of taxa, centers on the idea that organisms have limited resources, and investment in a particular function will come at the expense of others. Such trade-offs have major consequences for functional ecology: they constrain the range of possible trait combinations to a "spectrum" that provides opportunities for generalization across clades and habitats. They also provide a very valuable practical tool: functional traits that are costly and/or time-consuming to measure may be approximated by easier to measure "proxy" traits with which they are 
closely correlated. Many of the most widely measured traits in functional ecology fall in this category, such as the use of Leaf Mass per Area (LMA) as a predictor of leaf attributes such as leaf lifespan and photosynthetic rates in vascular plants (e.g. Wright et al. 2004) or Specific Thallus Mass (STM) as an indicator of water relations in lichens (Gauslaa \& Coxson 2011).

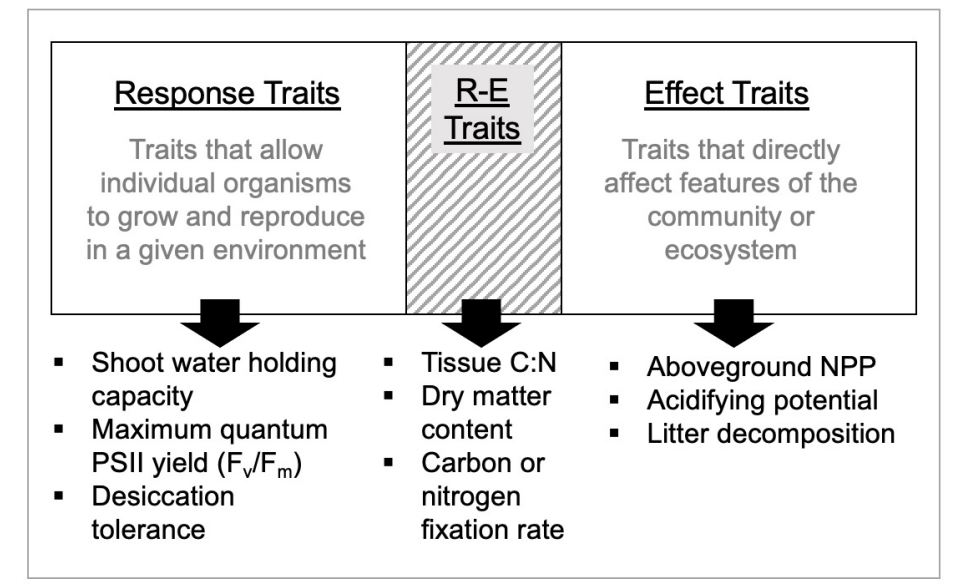

FIGURE 1. Response traits (R), effect traits (E) and response and effect traits (R-E) in plants and examples in bryophytes of each category.

"Economic" constraints are not the only ones affecting traits. Trait expression may also be impacted by biophysical, developmental, genetic and phylogenetic constraints. Biophysical constraints limit the possible combination of traits without losing structural integrity: for example large canopies must be supported by shoots that won't buckle under the weight (Niklas \& Spatz 2012). Developmental and genetic constraints can also be important, even if they can seem intractable to functional ecologists working with non-model organisms; for example, many genes are pleiotropic and so some trait combinations may be unlikely to evolve without disrupting other essential functions (Ortiz-Ramírez et al. 2016, Kirbis et al. 2020). Similarly, evolutionary legacy may play a large role in constraining traits and trait combinations (e.g. Hedenäs 2002, 2012, Coudert et al. 2017).

\section{Bryophytes are extremely evolutionarily and ecologically diverse}

Bryophytes are an evolutionarily and ecologically diverse assemblage. There has been recent controversy as to whether bryophytes are a monophyletic grouping or not (e.g. Renzaglia et al. 2018, Sousa et al. 2019, Bell et al. 2020, articles in this issue), but regardless of the reconstructions, the major clades diverged from their most recent common ancestor in the late Cambrian. These $\sim 500$ million years of evolution have led to a spectacular range of anatomical, morphological and physiological adaptations, occupying and indeed often shaping, nearly all terrestrial habitats. This diversity presents both challenges and opportunities for understanding how terrestrial autotrophs interact with their environments, as the existing frameworks, often based implicitly or explicitly on angiosperms, may only capture a fraction of the spectrum of bryophyte strategies. All too often, functional ecologists have sought to compare and contrast bryophytes to betterstudied tracheophytes, rather than developing a broader perspective in which tracheophytes represent just a special case, albeit quite ecologically successful, of land plant ecology.

While studies on plant functional ecology in some form have dated back to at least the late 19th century foundations of physiological plant ecology (Egerton 2013), there has been a growing interest in functional trait approaches across and within embryophyte clades, particularly with reference to trait proxies that can be easily measured. In spite of this historical and continued interest, and despite their incredible diversity and suites of adaptive strategies, bryophytes have received much less attention. We believe it is important to not only highlight the unique functional ecology of bryophytes using trait-based frameworks, but also describe how and why traditional approaches fall short in their application to bryophytes. A deeper understanding of functional trait relationships within bryophytes will enhance our understanding of biogeochemical cycling at many different scales and contribute to our predictive power on how terrestrial systems will respond to climate change. We center our description on three core aspects of bryophytes that are poorly represented in tracheophyte studies: (I) dynamic water content (including poikilohydry and desiccation 
tolerance), (II) multiple scales of interaction with environment, and (III) reproduction and life history. While studies of the functional ecology of bryophytes are not a new phenomenon, in this review we will primarily focus on studies from the past decade (since 2010) that seek to build on the functional ecology of the later 20th century (e.g. Smith 1982, Longton 1988, Bates \& Farmer 1992) and incorporate it into a functional traits framework (for reviews on previous work, see Cornelissen et al. 2007, Tuba et al. 2011, Hanson \& Rice 2014).

\section{Dynamic water content}

\section{Poikilohydry: a core adaptation driving traits}

If we are to develop a bryophyte-centered framework for physiological functional traits, the near ubiquity of poikilohydry seems like a lynchpin of trade-offs. Poikilohydry is very rare in tracheophytes, particularly in the embryophytes. As a result, one of the central assumptions of the Leaf Economic Spectrum is that since loss of leaf turgor is an often catastrophic event, this creates a trade-off between potential carbon gain and water loss rates. This assumption is considerably weakened for most bryophytes. While it remains true that carbon gain can only occur when tissues are hydrated, the consequences of drying are far less dramatic and in fact desiccation tolerance is very widespread if not quite universal in bryophytes.

\section{Desiccation tolerance}

Desiccation tolerance (DT), the ability to revive physiological functioning from an air-dried or quiescent state, is widespread among bryophytes (Proctor et al. 2007). While most heavily studied in dryland moss clades (e.g. Syntrichia Brid.), DT has been observed in taxa of mesic habitats such as bogs (e.g. Sphagnum L., Hajek \& Beckett 2008) and even in aquatic mosses that undergo seasonal inundation (e.g. Fontinalis Hedw., Cruz de Carvalho et al. 2019). The suite of mechanisms involved in DT are controlled by traits at the anatomical, physiological, and molecular level, all operating in concert during periods of drying, while desiccated, and when rehydrating (Oliver et al. 2000, Proctor et al. 2007). However, potentially due to apparent variation in DT within and across diverse bryophyte clades, standardized metrics for assessment of DT have yet to be developed. For example, a key aspect of DT involves recovery of the photosynthetic apparatus when tissues become rehydrated following a period of desiccation. While there is substantial evidence that measurement of carbon fixation (e.g. using infrared gas exchange) or maximum photosystem II yield (using chlorophyll fluorescence) upon rehydration can provide insight into photosynthetic recovery dynamics, yet we lack standardized protocols for conditions under which these measurement are taken, or how long after rehydration it is reasonable to conduct measurements. One approach that would allow for standardized measurements of DT would be to apply the notion of DT 'factors' pioneered in Syntrichia and Physcomitrella Bruch \& Schimp. (Greenwood \& Stark 2014, Slate et al. 2018, Coe et al. 2021) in which bryophyte shoots (or other life stages) can be evaluated based on their ability to survive and regain undried (control) levels of photosystem II yield and regeneration following exposure to different (i) rates of drying, (ii) relative humidities while dry, (iii) duration dry, and (iv) rates of rehydration.

Consideration of DT in bryophytes is particularly important in systems where DT enables bryophyte survival on substrates that are largely unavailable to tracheophytes (e.g. rock surfaces, dense/vertical bark). Similarly, due to poikilohydry and their ability to rapidly regain physiological function during brief periods of favorable conditions (e.g. small rainfall events), bryophytes may outcompete other plants in certain microclimates, or exhibit unique functional roles that capitalize on their ability to rapidly undergo wet-dry cycles. For example, Carvajal Janke \& Coe (2021) demonstrated that hydration from small rainfall events can facilitate biocrust moss mediated nitrogen $(\mathrm{N})$ transfer via fungal loops to nearby dryland shrubs as well as spatially isolated biocrust patches. Over large spatio-temporal scales, the functional significance of these bryophyte responses (and the ecological associations to which they are inexorably linked) in terms of primary productivity and nutrient cycling can be significant. Furthermore, within bryophyte clades, DT may be a trait that directly relates to biodiversity and biogeography, thus represents a strong candidate for inclusion in bryophyte-centric trait databases.

\section{Water transport}

The diversity of traits related to water transport in bryophytes is astounding. Although bryophytes are often described as "non-vascular" and poikilohydry is a central characteristic, water conducting cells may be ancestral to all land plants (Ligrone et al. 2000,2012) and some taxa have specialized internal conduction tissues that share many characteristics with tracheophyte xylem and phloem. These similarities have been long noted: Haberlandt (1886) and later Tansley and Chick (1901) report not just anatomical examinations, but also briefly mention experimental tests of internal transport 
in Polytrichum Hedw. and Pallavicinia Gray respectively. Further work, especially in the Polytrichaceae, followed in the 20th century (Bowen 1931, Mägdefrau 1935), culminating in the work of Charles Hébant in the 1960s-70s (Hébant 1968, 1973, 1977). This subject has received renewed attention recently with the recognition that vascular bryophytes in the Polytrichaceae can be functionally equivalent to tracheophytes in transport efficiency (Brodribb et al. 2020) and allometry (Atala \& Alfaro 2012). These vascular bryophytes, although quite tall for bryophytes $(>50 \mathrm{~cm})$, do not reach the size of larger tracheophytes, and, intriguingly, retain DT. The constraints imposed by this hybrid hydration strategy, as well as the functional ecology of moss and liverwort lineages with less-complex conductive structures, are key areas for future research.

In addition to the internal conducting tissues displayed by some bryophytes, numerous and diverse external water transport mechanisms are employed across the group. Capillary water held tightly against the surface of shoots is responsible for most of the variability in total water content (Proctor 2000) and can be instrumental in maintaining water balance. Leaf arrangement traits such as overlapping and tightly clasping leaves, paraphyllia among leaf bases, or specialized epi-foliar structures (e.g. leaf cups in which other leaves reside in Fissidens Hedw.) facilitate surface area for water adhesion as well as modification of the shoot-level microenvironment to retard water loss. At the leaf level, awns (hair points) have been implicated in processes from dew capture (Pan et al. 2016) to DT (Coe et al. 2019) and have been shown to vary in response to changing environmental conditions (Wang et al. 2019). Leaf costae, ranging in number and complexity in bryophyte leaves, may facilitate water storage in hyaline cells as well as hydraulic channeling towards stems. At the cellular level, structures such as papillae and mammillae can influence micro-scale water movement and adhesion in cavities while simultaneously maximizing gas exchange in convex protrusions (Dilks \& Proctor 1979).

Although specialized internal water conduction is usually viewed as an adaptation allowing taller plants, it is worth considering that hydroids are present in many small bryophytes. At smaller physical scales external water conduction can be as efficient as internal transport, and so the role of hydroids may require critical reexamination. Hydraulic integration of shoots can be disadvantageous (Rice 2012), and so hydroids have been proposed to play a role as fuses as well as conduits (Rice 2012, Stanton et al. 2014). More broadly, the scale and context of bryophytes needs to be kept in mind when evaluating traits, even (or especially) those that would seem to resemble those of tracheophytes.

\section{Multiple and taxon specific scales of interaction}

\section{Leaf, shoot, colony: what is the functional scale of a bryophyte?}

The co-occurrence of poikilohydry and internal water conduction (so key to homoiohydry in tracheophytes) may seem surprising, but is a good illustration of the complex scale hierarchy of bryophytes. Bryophytes span a wide range of sizes, from sub-millimeter ephemeral mosses to half-meter Polytrichaceae and extensive carpets, to multi-meter deep Sphagnum shoots in peatlands. Anatomical complexity or leaves and thalli also varies greatly, from barely a cell or two thick to thick structures with complex internal or external airspaces. Faced with this diversity, even considering the relevant scale of functional processes can be challenging. What structures and scale(s) are most useful when considering an organism's functional response to environment (functionally autonomous)? For example, when Waite \& Sack $(2010,2011)$ provided one of the first application of the tracheophyte Leaf Economic Spectrum to mosses, they included a nuanced discussion of structural analogies between bryophytes and angiosperm leaves, showing that canopy-rather than leaf-scale metrics more closely resembled tracheophyte leaves. This analogy has found some support in other work, such as a recent survey of non-stomatal conductance in bryophytes (Carriquí et al. 2019). Other authors, such as Rice et al. (2008), have argued that there are not simple mappings from leaf, shoot or canopies of Sphagnum to tracheophyte leaves, and seeking to frame bryophytes solely in relation to tracheophytes misses their unique organizational characteristics.

Some clarity, if no less complexity, emerges from setting aside morphological analogies to focus on the microenvironments at the sites of photosynthesis. The densely packed shoots of an acrocarp moss cushion may create close, humid microenvironments for photosynthesis in single-cell thick and cuticle-free leaves, making the individual leaves similar to mesophyll layers of an idealized angiosperm leaf (Waite \& Sack 2010). But such an analogy may not apply to the multistratose leaves of some tall mosses, that do not differ greatly in scale and open canopy structure from small tracheophytes (consider the confusion, by many students, of Polytrichum for conifer seedlings). And even the cushion-mesophyll analogy raises intriguing questions as to the rates of $\mathrm{CO}_{2}$ diffusion within cushions, the changes as shoot and leaf morphology change with hydration status, and the role of $\mathrm{CO}_{2}$ recapture from non-photosynthetic tissues 
and litter at the cushion base. And how are we to evaluate other moss morphologies, let alone the even greater range of form in liverworts?

Understanding the scale(s) of functional interaction with the environment is central to the correct interpretation of potential functional traits. Depending on the taxon, different scales of organization may be more or less functionally autonomous (Fig. 2). For many small bryophytes, such as simple small leafy liverworts, the experienced environment may be primarily driven by their surroundings, and shoot/colony morphology may have minimal functional autonomy whereas leaf and lobule shape might, with structural constraints (Renner 2015). Similarly, thallus anatomy may be the primary scale of function in complex thalloid liverworts and hornworts. But in taxa where shoots intermingle to form canopies (mostly but certainly not exclusively, acrocarpous mosses) the scaling becomes more complex, with multiple scales of organization being of functional importance (Fig. 2).
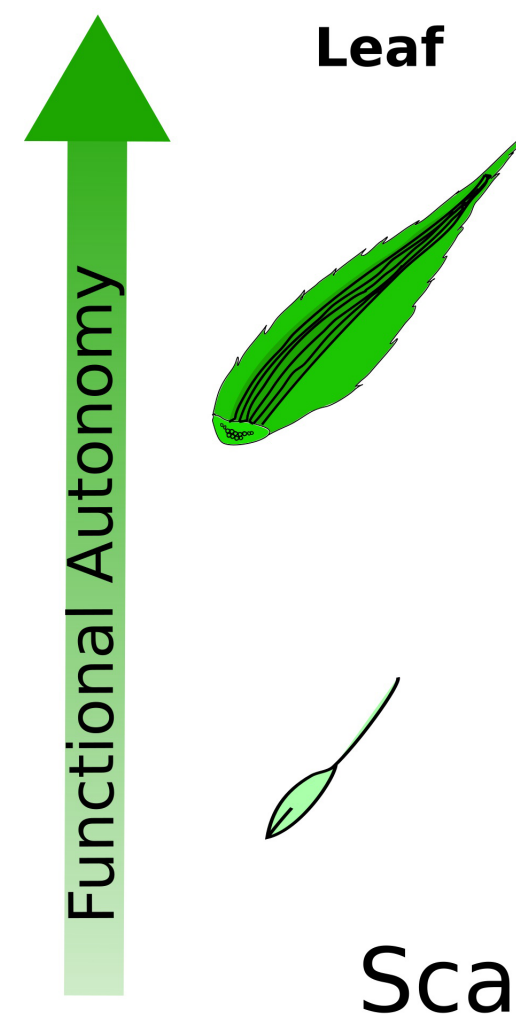

Shoot
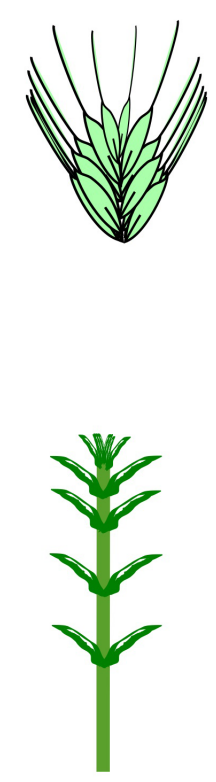

Colony
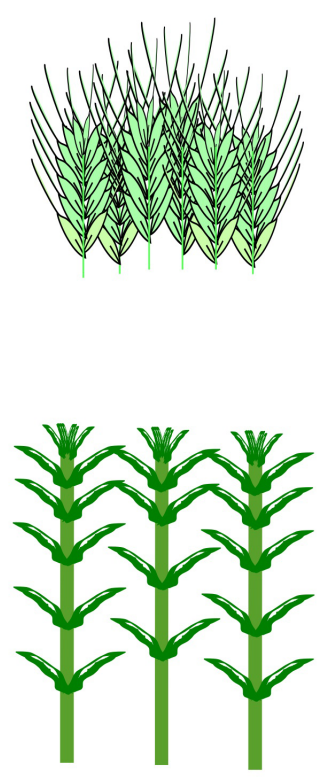

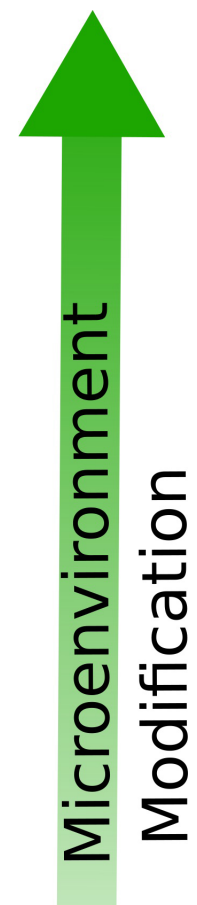

\section{Scale of organization}

FIGURE 2. Examples of varying degrees of functional autonomy of different scales of bryophyte organization. Structures with large impacts on their microenvironment (e.g. complex leaves, tightly packed colonies, etc) are expected to have greater functional autonomy and should be targets of study. Although two idealized acrocarpic mosses are shown as contrasting examples, similar considerations should apply to other bryophytes, with the functionally important scale of analysis differing between taxa and habitats.

In bryophytes with densely packed canopies, leaf and shoot level characteristics may show a response to the environment that is mediated by their effect on cushion or colony properties. For example, Oke \& Turetsky (2020) suggest that colonial growth of Sphagnum may constrain the potential for local adaptation of leaf and canopy. Additionally, one might also expect some traits at the leaf scale may be under weakened selective pressure from the environment due to the mediation of larger-scales: for example, even Antarctic mosses can have relatively high temperature optima due to the warm microclimates created by dense cushions (Perera-Castro et al. 2020). Similarly, Niinemets \& Tobias (2019) found that despite very high structural diversity in moss canopies, there is a comparative convergence in some aggregate characteristics such as Leaf Area Index (LAI). This would lead to a risk of over-interpreting the adaptive significance of trait variance if the wrong scale is examined. It is worth noting that this nested scale challenge is hardly unique to bryophytes, just harder to overlook than at the biophysical scales of most tracheophyte growth-forms.

Despite their small size, the biophysics of bryophyte canopies can be complex, and reflect the integration of 
properties across scales. Canopy structure not only drives light penetration (Zotz \& Kahler 2007), evaporation (Elumeeva et al. 2011, Cruz de Carvalho et al. 2019) and temperature (Rice et al. 2018), but these properties change with hydration status (e.g. Zotz \& Kahler 2007, Rice et al. 2011, 2018) and even compression (Granath et al. 2018). A striking example of the intermingling of scales comes from the ecological model moss clade Syntrichia: hyaline leaf bases and awns, ostensibly leaf-level traits, affect leaf spreading during wetting and drying (Wu et al. 2014), with consequences for canopy boundary layer and ultimately carbon balance (Coe et al. 2019). This interdependence of scales poses an additional challenge to the development of consistent trait frameworks: multiple anatomically disparate leaf-scale characteristics may lead to similar canopy-scale attributes (Niinemets \& Tobias 2019).

Hierarchical organization is one of the reasons that traits are rarely independent characteristics of an organism or taxon. Developmental and "economic" constraints also impose trade-offs that lead to the emergence of correlated suites of traits. Identifying these correlations brings practical advantages: traits that are low-cost or effort to measure may be used as proxies for more difficult ones, and taxa may be grouped into functional groups (e.g. "Plant Functional Types") with similar trait combinations, simplifying ecological studies. While in some cases these groupings may resemble the more traditional "life-form" or "growth-form" types of classification, they regularly do not (e.g. Fan et al. 2020). While trait correlations have been identified with photosynthetic traits (Waite \& Sack 2011, Wang et al. 2014, 2017a\&b, Mazziotta et al. 2019), the relationship between photosynthetic traits and water relations is more complicated, and potentially phylogenetically constrained (Wang \& Bader 2018). Life-form classification is still widely used in bryophyte ecology studies, and indeed can hold considerable predictive power for bryophyte communities (e.g. Berdugo \& Dovciak 2019, Spitale et al. 2020), and so there is a strong need to identify its potential and limitations with respect to functional physiology.

\section{Reproduction and life history}

Physiological traits, in particular those associated with carbon economy and water dynamics, have been the focus of our discussions so far. However, a separate and productive line of research has studied reproductive traits, from sex expression to trade-offs between propagule type and dispersal/colonization.

Many bryophyte species produce more than one propagule type, including a very wide range of specialized asexual propagules from the gametophytic stage (bulbils, gemmae, fragments, etc.; Frey \& Kürschner 2011). Sexual and asexual propagules differ in size, with functional consequences for dispersal distance and likelihood of successful establishment (Laaka-Lindberg et al. 2003, Pohjamo et al. 2006). These traits shape species distributions and community structure (e.g. Patiño et al. 2013, Löbel et al. 2018, Tiselius et al. 2019). For example, Sierra et al. (2019) have shown that propagule characteristics predict succession in high diversity tropical epiphyll community. Even within a species, primary propagule type can vary according to habitat and population (e.g. Maciel-Silva et al. 2013, Blackstock 2018). Within propagule types, size (Löbel \& Rydin 2010), morphology (Zanatta et al. 2016) and stress tolerance (Estébanez et al. 2018) may play important roles in determining dispersal distances.

Reproduction may also have consequences for physiological functional traits. In most cases, sporophytes are dependent on the parent gametophyte (Haig 2013), which, along with other differences associated with sex expression, can lead to greater physiological costs in female-expressing plants (but see Stark et al. 2000). While work in this area remains limited, some recent studies point to effects of sex on physiological functional traits in Ceratodon purpureus (Hedw.) Brid. (larger leaves and higher photosynthesis in females, Slate et al. 2017), water holding capacity (greater in females, Moore et al. 2016) and microbiome (Castetter et al. 2019) in Bryum argenteum Hedw. and desiccation tolerance in Marchantia inflexa Nees \& Mont. (greater in females in some populations, Marks et al. 2019a). Further work in this area is clearly needed.

Sporophyte characteristics have long been considered from a taxonomic perspective, but their functional importance deserves further attention. Sporophyte traits can affect both water and nutrient status of the maternal plant, and the dispersal conditions and distance of the spores (Johansson et al. 2014). The sporophyte have been described as a "filial mistletoe", and therefore increase water loss from the parent as an adaptation to obtain nutrients (Haig 2013). In mosses, the calyptra (a gametophytic structure, but closely associated with the sporophyte) plays an important role in regulation of water loss, with likely consequences for the parent plant (Budke \& Goffinet 2016, Budke 2019). The convergent evolution of characteristics such as sporangium shape (Rose et al. 2016) and loss of stomata (Renzaglia et al. 2020) also present promising avenues for further functional interpretation.

Life history attributes such as life span and phenology also greatly impact functional traits. While attention is 
most often given to long-lived perennial bryophytes, many species are much more ephemeral, exploiting temporary availability of water or light in seasonal environments. These habits select for very different growth and reproductive allocation, leading to convergent trait combinations associated with life-history strategies in mosses (Hedderson and Longton 1995, 1996) and liverworts (Manyanga et al. 2011). For example, more ephemeral species would be expected to invest in rapid growth and high reproductive allocation, at the expense of stress-tolerance traits. However, a few caveats are worth considering: DT may reduce the "cost" of water loss and some seemingly ephemeral taxa may actually form perennial organs (e.g. tubers and bulbils in Bryum Hedw., Pressel et al. 2007), shifting their reproductive investment. These life-histories have been well studied, but the resulting interaction with functional traits is an open area for future work. An important but sometimes overlooked component of the tracheophyte Leaf Economic Spectrum is leaf longevity (Wright et al. 2004): for example, in what form do equivalent trade-offs appear in the physiology of bryophyte leaves and shoots? How do additional characteristics such as mating mode, dispersal strategy (and therefore spore size) interact with these life-histories?

\section{Within-species trait variation: phenotypic plasticity and local adaptation}

An irony of the functional trait perspective to morphology and anatomy is that it often works best on those characters most frustrating to systematists and taxonomists, those showing the greatest environmental response. In most of the examples discussed thus far this involves convergent adaptations by independent lineages. A similarly informative context emerges from the consideration of within-species variation, which can arise both from differences between populations of the same species (genotypic variation, including local adaptation) and environmental variability within a genotype (phenotypic plasticity). The dramatic morphological variability of bryophytes has long been a challenge to bryologists. Building on the experimental botany foundations of Schimper, Haberlandt and others, several authors over the course of the 20th century experimentally studied intra-specific plasticity in bryophytes in response to growth environment. For example, Davy de Virville (Davy de Virville \& Douin 1921, Davy de Virville 1927) showed that humidity and light can lead to dramatic changes in leaf and stem morphology in several species of mosses and liverworts. Many of these early experiments involved what might seem like extreme changes in conditions (complete submersion in water, sealed humid atmospheres, complete darkness). An important milestone is the work of Forman with Tetraphis pellucida Hedw. (Forman 1964). In this study, not only was growth and leaf morphology experimentally related to temperature and relative humidity, but these characteristics were also placed into a hierarchical framework of organization spanning from large geographic patterns to clump and shoot scales.

In recent years, several studies have drawn on modern trait and genetic techniques, in combination with transplant and common garden experiments, to show striking importance of phenotypic plasticity and local adaptation (Coe et al. 2019). For example, recent work in Sphagnum (e.g. Granath et al. 2009, Oke \& Turetsky 2020) suggests that both factors can strongly influence functional traits at different scales. Morphometric approaches can also be combined with genetics across large geographic scales (e.g. Pereira et al. 2013, Wang et al. 2019). Besides vegetative characters, both phenotypic plasticity and local adaptation can also interact with reproductive tradeoffs (Hedderson \& Longton 2008. 2013, Marks et al. 2016, Bisang et al. 2020). Promisingly, phenotypic plasticity is an area in which our growing understanding of model bryophyte taxa provides a valuable genomic context that should be extendable to non-model taxa (McDaniel 2018).

\section{Ecosystem effects of traits}

Much of the focus of this review has been on response traits, however, another important category of traits are effect traits, that is, those with direct ecosystem effects (see Fig. 1). Across ecosystems, bryophytes influence various aspects of biogeochemical cycling (Cornelissen et al. 2007) and mediate plant-soil interactions and feedbacks. Referred to collectively as the 'bryosphere' (Lindo \& Gonzalez 2010), bryophytes offer a number of unique and related effects on ecosystem processes. For example, due to their tolerance of low temperatures and low/intermittent water availability compared to trees and other tracheophytes, mosses across the boreal forest biome can account for up to $50 \%$ of the annual gross primary productivity in these regions (Goulden \& Crill 1997, Kolari et al. 2006). In boreal forests as well as peatlands, temperate forests, and tundra systems, bryophytes can contribute up to $50 \%$ of ecosystem $\mathrm{N}$ inputs through symbiotic associations with N-fixing cyanobacteria (DeLuca et al. 2002, Rousk et al. 2017). Further, in dryland systems, mosses act as a keystone species in biocrust communities (Reed et al. 2012, Coe \& Sparks 2014), such that their removal dramatically alters $\mathrm{N}$ cycling in terms of $\mathrm{N}$ form and availability. The effect of bryophytes on $\mathrm{N}$ cycling is likely far more ubiquitous and widespread than we are currently aware (Elbert et al. 2012, Porada et al. 2014), and is a strong effect trait candidate for exploration in future trait databases across terrestrial ecosystems.

Due to their often close proximity to the soil surface in many systems, bryophytes can also exert control on 
numerous soil properties ranging from temperature (Porada et al. 2016, Moore et al. 2019, Xiao \& Bowker 2020) to water holding capacity (Elumeeva et al. 2011, Soudzilovskaia et al. 2011, Moore et al. 2019) to decomposition (Cornelissen et al. 2007, Zuijlen et al. 2020). The impacts of bryophytes on hydrology have begun to receive increasing attention in recent years, associated with the growing field of ecohydrology. Although the role of Sphagnum in wetland hydrology has a long history of study, other taxa can have large influences in other habitats. In tropical montane environments, fog interception by bryophytes can significantly increase water inputs and storage (Chang et al. 2002, Villegas et al. 2008, Ah-Peng et al. 2017). Bryophytes in soil crusts affect infiltration and runoff (Xiao et al. 2019, Eldridge et al. 2020). Global modelling suggests a considerable hydrological influence of bryophytes (and lichens) on rainfall interception (Porada et al. 2018), and soil hydraulic conductivity (Voortman et al. 2014) but also highlights the absence of empirical data for much of the globe.

These impacts of bryophytes are fundamental to primary succession in many modern contexts (Mueller-Dombois \& Boehmer 2013, Arróniz-Crespo et al. 2014, Vilmundardóttir et al. 2018). Because of their deep geological history, early terrestrial environments are also likely to have been shaped by bryophytes (Lenton et al. 2016). Considerable caution is nonetheless necessary in interpreting the paleoecological effects of bryophytes: our modern species are not static snapshots of a distant past. Many of the effect traits and indeed lineages of present-day bryophytes may be far more recent and reflect diversification in angiosperm dominated ecosystems (Laenen et al. 2014, for a lichen-based discussion of this topic see Nelsen et al. 2020).

Ecosystem effects of bryophyte traits may also include traits that influence or facilitate interactions with other species. For one, it has long been surmised that mycorrhizal interactions evolved concomitantly with the evolution of land plants (Pressel et al. 2014). Fungal symbioses have been widely demonstrated across liverworts and are present in hornworts as well, yet appear to have been lost in mosses, where it has been suggested that rhizoids may play a comparable role (Field \& Pressel 2018). Mosses also host similar endophytic fungi to co-occurring lichens and tracheophytes (U'Ren et al. 2010, 2019), and may play a role in maintaining subterranean fungal connections for nutrient translocation between spatially isolated biocrusts and vascular plants (Carvajal Janke \& Coe 2021).

A variety of secondary metabolites have also been observed in mosses and liverworts that affect biotic or pathogenic interactions with fungi, bacteria, vascular plants, and animals. Such chemicals have been shown to influence the ability of bryophytes to resist pathogens as well as their palatability to animal consumers. Recently, Peters et al. (2019) noted the presence of sesquiterpenoids and flavonoids, compounds that function to deter herbivores, provide constitutive defenses, and potentially have allelopathic outcomes, in nine different species of bryophytes. Seasonal variation in these compounds also appears to exist, where chemical richness within the compound classes peaked in the spring and summer in Marchantia L. and Polytrichum, and in the winter in Brachythecium Schimp. (Peters et al. 2019). Biochemical synthesis and expression of such chemical traits is thus likely to be driven by seasonally fluctuating biotic and abiotic conditions.

While some classes of secondary metabolites in bryophytes inhibit consumption or colonization by other species, bryophytes may also serve as a food source for several groups of consumers. Aquatic and terrestrial mosses have been shown to represent a potentially important food supply for invertebrates (Suren \& Winterbourn 1991, Haines \& Renwick 2009), yet this effect is very species specific and likely relates to pre-ingestion chemical traits or deterrents. Bryophytes can also represent a food source for vertebrate animals, particularly birds, where consumption of gametophyte as well as sporophyte components of shoots has been documented (Martin \& Hik 1992, Stech et al. 2011, Russo et al. 2020).

\section{What are the gaps in our functional trait studies?}

Although the number of studies on bryophyte functional traits has greatly increased in recent years, a cohesive trait framework (or frameworks) is still distant. Three areas in particular need attention: the still limited and biased sources of trait information, broader perspectives as to what constitutes a functional trait, and better shared protocols and databases across research groups.

Bryophyte functional ecology studies have, quite understandably, favored the taxa and environments with practical advantages to researchers, which inevitably introduces biases. A majority of studies have focused on larger bodied mosses, as well as a few liverworts. Such a bias is understandable from a practical standpoint, much of the instrumentation has been developed for larger bodied organisms, and precision can be more difficult to obtain with small bryophytes. Mosses, especially acrocarps, also offer the greatest apparent morphological similarity to angiosperms, which can make them seem easier to align with existing functional trait frameworks, even if the validity of that alignment is sometimes debatable.

A significant exception to this size bias is the continued work on Physcomitrium (= Physcomitrella) patens (Hedw.) Mitt. and Marchantia polymorpha L. as model systems, however, there is a need for better integration of this 
information with functional and ecological perspectives. The expansion of genomic and transcriptomic tools for other bryophytes such as Anthoceros L. (Szövényi 2016, Li et al. 2020, Zhang et al. 2020), Marchantia (Marks et al. 2019b), Pleurozium Mitt. (Pederson et al. 2019), Sphagnum (Shaw et al. 2016), and Tortula Hedw. (Syntrichia) (Oliver et al. 2010), as well a rapidly expanding number of plastid and mitochondrial genomes (e.g. Dong et al. 2019) is beginning to bridge this gap between molecular and organismal perspectives.

Biased selection of study taxa can also have other impacts on our understanding of traits. Traits and trait correlations are often phylogenetically constrained (Cavender-Bares et al. 2009), and so interspecific comparison studies would benefit from greater consideration of phylogenetic context. This incorporation of evolutionary history can be limited by the availability of reliable phylogenies, however our understanding of bryophyte evolution is rapidly advancing. Recent studies provide examples of the incorporation of phylogenetic context at the genus (Piatkowski \& Shaw 2019) and habitat (Fernández-Martínez et al. 2019) scales. Hedderson \& Longton (1996) related phylogeny, life-history and traits associated with water-relations (water conducting tissues, leaf shape and papillosity), a re-examination of this work might be conducted using updated phylogenies and analytic tools. Even when quantitative evaluation of evolutionary constraints is not possible, the consideration of its possible role may enrich the interpretation of results.

Geographic biases also constrain our current understanding of bryophyte functional ecology. Despite some recent studies of tropical (e.g. Sierra et al. 2019, Marks et al. 2019a), sub-tropical (e.g. Wang et al. 2017b, Fan et al. 2020) and mediterranean (e.g. Fernández-Martínez et al. 2019, Spitale et al. 2020) biomes, much of the work continues to focus on higher-latitude ecosystems, especially in the northern hemisphere. This bias is perhaps less marked than in some other taxa, but leaves much of the diversity of bryophyte lineages and habitats understudied. For example, despite a high diversity of species and morphologies, tropical leafy liverworts have received comparatively little ecological attention. Similarly, numerous evolutionary distinct moss orders (e.g. Andreaeales, Rhizogoniales, Hypnodendrales, Ptychomniales, Hookeriales, etc.) and the majority of liverwort and hornwort orders appear to be largely absent from functional trait studies. This bias also applies to the understanding of community and ecosystem impacts of bryophytes: many biomes and regions are represented by at best one or two studies (e.g. see Mallen-Cooper \& Cornwell 2020 for a review of biases in transplant experiments).

One ecosystem impact that has received increasing attention in the last two decades is the influence of bryophytes on various metrics of $\mathrm{N}$ cycling (see Ecosystem Effects of Traits above). However, our information is currently largely limited to high-latitude systems in the Northern Hemisphere, when evidence suggests that the processes involved in $\mathrm{N}$ cycling contributed by bryophytes (namely symbiotic associations with $\mathrm{N}$ fixing diazotrophs such as cyanobacteria) may exist across terrestrial ecosystems, including temperate forests (Deane-Coe \& Sparks 2015), and peatlands (Saiz Val 2020). Relatedly, our knowledge of the microbial communities, N-fixing and otherwise, associated with bryophytes is scant, and mostly limited to several studies based on Sphagnum (e.g. Kostka et al. 2016). Information on how bryophyte microbiomes vary as a function of, and influence, environmental stress is largely lacking (but see Jean et al. 2020), yet is crucial to our understanding of how bryophytes and their associated microbiomes will cope with climate change. The bryophyte microbiome can even be thought of as a trait in itself, and is likely to vary across species in association with some anatomical features. For example, the lobules of leafy liverworts can harbor microbial and microinvertebrate communities, even to the point of zoophagy (Barthlott et al. 2000, Hess et al. 2005); it seems reasonable to expect a relationship between lobule shape and microbiome composition. Traits related to (or even directly characterizing) the microbiome thus warrant inclusion in bryophyte trait databases moving forward.

Among the most important challenges is the need for an expansive, bryophyte-centric suite of traits, as well as ideally widely shared protocols for their measurement and databases for their dissemination. Some examples already exist (Cornelissen et al. 2007, Henriques et al. 2017) as foundations, but there remains a need for greater coordination. Ideally, these frameworks can be developed to favor the inclusion of previously understudied clades and locations. We argue that these trait concepts need to be expansive and consider features that may not have traditionally been considered "traits" such as bryophyte-associated microbiomes. Ideally such frameworks might also accommodate functionally equivalent but anatomically distinct traits, perhaps through the explicit incorporation of multiple scales of organization. We do not claim to have a complete solution, or even that a single one exists, but rather call for a collaborative effort bridging bryophyte physiologists, ecologists, taxonomists and developmental biologists.

\section{Conclusions}

Bryophytes "aren't just small tracheophytes" (Mishler 2001), they represent a very broad spectrum of life-history strategies for life on land, of which tracheophytes are but one example (albeit successful in some environments). There 
is a pressing need to develop frameworks that bridge between anatomy, morphology and physiology of bryophytes that leverage this striking evolutionary diversity. These perspectives are important not only to understanding bryophyte ecology, but also inform evolutionary history and the global consequences of bryophytes past and present. The field of bryophyte functional ecology has seen a promising acceleration of studies in the past decade, many of them led by a diverse, globally distributed assemblage of young researchers, building on foundational work in the late 19th and 20th centuries. Nonetheless, many gaps and biases in knowledge persist. The time is now ripe to build a synthetic framework of land plant functional ecology that transcends phylogenetic, geographic and historic biases.

\section{References}

Ah-Peng, C., Cardoso, A.W., Flores, O., West, A., Wilding, N., Strasberg, D. \& Hedderson, T.A.J. (2017) The role of epiphytic bryophytes in interception, storage, and the regulated release of atmospheric moisture in a tropical montane cloud forest. Journal of Hydrology, 548: $665-673$.

https://doi.org/10.1016/j.jhydrol.2017.03.043

Arróniz-Crespo, M., Pérez-Ortega, S., Ríos, A.D. los, Green, T.G.A., Ochoa-Hueso, R., Casermeiro, M.Á., de la Cruz, M.T., Pintado, A., Palacios, D., Rozzi, R., Tysklind, N. \& Sancho, L.G. (2014) Bryophyte-Cyanobacteria Associations during Primary Succession in Recently Deglaciated Areas of Tierra del Fuego (Chile). PLOS ONE 9: e96081. https://doi.org/10.1371/journal.pone.0096081

Atala, C. \& Alfaro, J.F. (2012) Vascular architecture of the dendroid antipodean moss Dendroligotrichum dendroides (Brid. ex Hedw.) Broth. (Polytrichaceae). Journal of Bryology 34: 277-280. https://doi.org/10.1179/1743282012Y.0000000032

Barthlott, W., Fischer, E., Frahm, J.-P. \& Seine, R. (2000) First Experimental Evidence for Zoophagy in the Hepatic Colura. Plant Biology 2: $93-97$.

https://doi.org/10.1055/s-2000-9150

Bates, J.W. \& Farmer, A.M. (1992) Bryophytes and lichens in a changing environment. Clarendon Press.

Bell, D., Lin, Q., Gerelle, W.K., Joya, S., Chang, Y., Taylor, Z.N., Rothfels, C.J., Larsson, A., Villarreal, J.C., Li, F.-W., Pokorny, L., Szövényi, P., Crandall-Stotler, B., DeGironimo, L., Floyd, S.K., Beerling, D.J., Deyholos, M.K., von Konrat, M., Ellis, S., Shaw, A.J., Chen, T., Wong, G.K.-S., Stevenson, D.W., Palmer, J.D. \& Graham, S.W. (2020) Organellomic data sets confirm a cryptic consensus on (unrooted) land-plant relationships and provide new insights into bryophyte molecular evolution. American Journal of Botany 107: 91-115. https://doi.org/10.1002/ajb2.1397

Berdugo, M.B. \& Dovciak, M. (2019) Bryophytes in fir waves: Forest canopy indicator species and functional diversity decline in canopy gaps. Journal of Vegetation Science 30: 235-246. https://doi.org/10.1111/jvs.12718

Bisang, I., Ehrlén, J. \& Hedenäs, L. (2020) Sex expression and genotypic sex ratio vary with region and environment in the wetland moss Drepanocladus lycopodioides. Botanical Journal of the Linnean Society 192: 421-434. https://doi.org/10.1093/botlinnean/boz063

Blackstock, T.H. (2018) Apparent increase in fertility of Lunularia cruciata (L.) Lind. (Marchantiophyta) in Britain associated with climate change. Journal of Bryology 40: 377-383. https://doi.org/10.1080/03736687.2018.1514175

Bowen, E.J. (1931) Water Conduction in Polytrichum commune. Annals of Botany 45: 175-200. https://doi.org/10.1093/oxfordjournals.aob.a090265

Brodribb, T.J., Carriquí, M., Delzon, S., McAdam, S.A.M. \& Holbrook, N.M. (2020) Advanced vascular function discovered in a widespread moss. Nature Plants 6: 273-279. https://doi.org/10.1038/s41477-020-0602-x

Budke, J.M. (2019) The moss calyptra: A maternal structure influencing offspring development. The Bryologist 122: 471-491. https://doi.org/10.1639/0007-2745-122.3.471

Budke, J.M. \& Goffinet, B. (2016) Comparative Cuticle Development Reveals Taller Sporophytes Are Covered by Thicker Calyptra Cuticles in Mosses. Frontiers in Plant Science 7: 832.

https://doi.org/10.3389/fpls.2016.00832

Carriquí, M., Roig-Oliver, M., Brodribb, T.J., Coopman, R., Gill, W., Mark, K., Niinemets, Ü., Perera-Castro, A.V., Ribas-Carbó, M., Sack, L., Tosens, T., Waite, M. \& Flexas, J. (2019) Anatomical constraints to nonstomatal diffusion conductance and photosynthesis 
in lycophytes and bryophytes. New Phytologist 222: 1256-1270.

https://doi.org/10.1111/nph.15675

Carvajal Janke, N. \& Coe, K.K. (2021) Evidence for a fungal loop in shrublands. Journal of Ecology. [Online early] https://doi.org/10.1111/1365-2745.13610

Castetter, R.C., McLetchie, D.N., Eppley, S.M. \& Stark, L.R. (2019) Sex ratio and sex expression in an urban population of the silver moss, Bryum argenteum Hedw. Journal of Bryology: 1-9. https://doi.org/10.1080/03736687.2019.1610617

Cavender-Bares, J., Kozak, K.H., Fine, P.V.A. \& Kembel, S.W. (2009) The merging of community ecology and phylogenetic biology. Ecology Letters 12: 693-715. https://doi.org/10.1111/j.1461-0248.2009.01314.x

Chang, C., Shih-Chieh, Lai, I.-L. \& Wu, J.-T. (2002) Estimation of fog deposition on epiphytic bryophytes in a subtropical montane forest ecosystem in northeastern Taiwan. Atmospheric Research 64: 159-167. https://doi.org/10.1016/S0169-8095(02)00088-1

Coe, K.K. \& Sparks, J.P. (2014) Physiology-based prognostic modeling of the influence of changes in precipitation on a keystone dryland plant species. Oecologia 176 (4): 933-942. https://doi.org/10.1007/s00442-014-3067-7

Coe, K.K., Howard, N.B., Slate, M.L., Bowker, M.A., Mishler, B.D., Butler, R., Greenwood, J. \& Stark, L.R. (2019) Morphological and physiological traits in relation to carbon balance in a diverse clade of dryland mosses. Plant, Cell \& Environment 42: 3140-3151. https://doi.org/10.1111/pce.13613

Coe, K.K., Greenwood, J.L., Slate, M.L., Clark, T.A., Brinda, J.C., Fisher, K.M., Mishler, B.D., Bowker, M.A., Oliver, M.J., Ebrahimi, S. \& Stark, L.R. (2021) Strategies of desiccation tolerance vary across life phases in the moss Syntrichia caninervis. American Journal of Botany 108: 249-262. https://doi.org/10.1002/ajb2.1571

Cornelissen, J.H.C., Lang, S.I., Soudzilovskaia, N.A. \& During, H.J. (2007) Comparative Cryptogam Ecology: A Review of Bryophyte and Lichen Traits that Drive Biogeochemistry. Annals of Botany 99: 987-1001. https://doi.org/10.1093/aob/mcm030

Coudert, Y., Bell, N.E., Edelin, C. \& Harrison, C.J. (2017) Multiple innovations underpinned branching form diversification in mosses. New Phytologist 215: 840-850. https://doi.org/10.1111/nph.14553

Cruz de Carvalho, R., Maurício, A., Pereira, M.F., Marques da Silva, J. \& Branquinho, C. (2019) All for One: The Role of Colony Morphology in Bryophyte Desiccation Tolerance. Frontiers in Plant Science 10: 1360. https://doi.org/10.3389/fpls.2019.01360

Davy de Virville, Ad. (1927) L'action du milieu sur les mousses. Revue de Botanique 462-471: 364-383, 449-457, 515-522, 560-586, 638-662, 711-726, 767-783, 30-44, 95-110, 156-173.

Davy de Virville, Ad. \& Douin, R. (1921) Sur les modifications de la forme et la structure des hépatiques maintenues submergées sous l'eau. Comptes rendus hebdomadaires des séances de l'Académie des sciences 8: 1306-1308.

Deane-Coe, K.K. \& Sparks, J.P. (2015) Cyanobacteria associations in temperate forest bryophytes revealed by $\delta 15 \mathrm{~N}$ analysis. The Journal of the Torrey Botanical Society 143 (1): 50-57. https://doi.org/10.3159/TORREY-D-15-00013

DeLuca, T.H., Zackrisson, O., Nilsson, M.-C. \& Sellstedt, A. (2002) Quantifying nitrogen-fixation in feather moss carpets of boreal forests. Nature 419: 917-920. https://doi.org/10.1038/nature01051

Dilks, T.J.K. \& Proctor, M.C.F. (1979) Photosynthesis, respiration and water content in bryophytes. New Phytologist 82 (1): $97-114$. https://doi.org/10.1111/j.1469-8137.1979.tb07564.x

Dong, S., Zhao, C., Zhang, S., Zhang, L., Wu, H., Liu, H., Zhu, R.-L., Jia, Y., Goffinet, B. \& Liu, Y. (2019) Mitochondrial genomes of the early land plant lineage liverworts (Marchantiophyta): conserved genome structure, and ongoing low frequency recombination. BMC Genomics 20: 953. https://doi.org/10.1186/s12864-019-6365-y

Egerton, F.N. (2013) History of Ecological Sciences, Part 48: Formalizing Plant Ecology, about 1870 to mid-1920s. Bulletin of the Ecological Society of America 94: 341-378. https://doi.org/10.1890/0012-9623-94.4.341

Elbert, W., Weber, B., Burrows, S., Steinkamp, J., Büdel, B., Andreae, M.O. \& Pöschl, U. (2012) Contribution of cryptogamic covers to the global cycles of carbon and nitrogen. Nature Geoscience 5: 459-462.

https://doi.org/10.1038/ngeo1486 
Eldridge, D.J., Reed, S., Travers, S.K., Bowker, M.A., Maestre, F.T., Ding, J., Havrilla, C., Rodriguez-Caballero, E., Barger, N., Weber, B., Antoninka, A., Belnap, J., Chaudhary, B., Faist, A., Ferrenberg, S., Huber-Sannwald, E., Issa, O.M. \& Zhao, Y. (2020) The pervasive and multifaceted influence of biocrusts on water in the world's drylands. Global Change Biology 26: 6003-6014. https://doi.org/10.1111/gcb.15232

Elumeeva, T.G., Soudzilovskaia, N.A., During, H.J. \& Cornelissen, J.H.C. (2011) The importance of colony structure versus shoot morphology for the water balance of 22 subarctic bryophyte species: Factors affecting bryophyte water balance. Journal of Vegetation Science 22: 152-164. https://doi.org/10.1111/j.1654-1103.2010.01237.x

Estébanez, B., Medina, N.G., Caparrós, R., Monforte, L., Del-Castillo-Alonso, M.-Á., Martínez-Abaigar, J. \& Núñez-Olivera, E. (2018) Spores potentially dispersed to longer distances are more tolerant to ultraviolet radiation: A case study in the moss genus Orthotrichum. American Journal of Botany 105: 996-1008. https://doi.org/10.1002/ajb2.1118

Fan, X.-Y., Liu, W.-Y., Song, L., Liu, S., Shi, X.-M. \& Yuan, G.-D. (2020) A combination of morphological and photosynthetic functional traits maintains the vertical distribution of bryophytes in a subtropical cloud forest. American Journal of Botany 107: 761-772. https://doi.org/10.1002/ajb2.1474

Fernández-Martínez, M., Berloso, F., Corbera, J., Garcia-Porta, J., Sayol, F., Preece, C. \& Sabater, F. (2019) Towards a moss sclerophylly continuum: Evolutionary history, water chemistry and climate control traits of hygrophytic mosses. Functional Ecology 33: $2273-$ 2289.

https://doi.org/10.1111/1365-2435.13443

Field, K.J. \& Pressel S. (2018) Unity in diversity: structural and functional insights into the ancient partnerships between plants and fungi. New Phytologist 220: 996-1011. https://doi.org/10.1111/nph.15158

Forman, R.T.T. (1964) Growth under Controlled Conditions to Explain the Hierarchical Distributions of a Moss, Tetraphis pellucida. Ecological Monographs 34: 1-25. https://doi.org/10.2307/1948461

Frey, W. \& Kürschner, H. (2011) Asexual reproduction, habitat colonization and habitat maintenance in bryophytes. Flora 206 (3): $173-$ 184. https://doi.org/10.1016/j.flora.2010.04.020

Gauslaa, Y. \& Coxson, D. (2011) Interspecific and intraspecific variations in water storage in epiphytic old forest foliose lichens. Botany 89: 787-798. https://doi.org/10.1139/b11-070

Goulden, M.L. \& Crill, P.M. (1997) Automated measurements of $\mathrm{CO}_{2}$ exchange at the moss surface of a black spruce forest. Tree Physiology 17: $537-542$. https://doi.org/10.1093/treephys/17.8-9.537

Granath, G., Strengbom, J., Breeuwer, A., Heijmans, M.M.P.D., Berendse, F. \& Rydin, H. (2009) Photosynthetic performance in Sphagnum transplanted along a latitudinal nitrogen deposition gradient. Oecologia 159: 705-715. https://doi.org/10.1007/s00442-008-1261-1

Granath, G., Rydin, H., Baltzer, J.L., Bengtsson, F., Boncek, N., Bragazza, L., Bu, Z.-J., Caporn, S.J.M., Dorrepaal, E., Galanina, O., Gałka, M., Ganeva, A., Gillikin, D.P., Goia, I., Goncharova, N., Hájek, M., Haraguchi, A., Harris, L.I., Humphreys, E., Jiroušek, M., Kajukało, K., Karofeld, E., Koronatova, N.G., Kosykh, N.P., Lamentowicz, M., Lapshina, E., Limpens, J., Linkosalmi, M., Ma, J.-Z., Mauritz, M., Munir, T.M., Natali, S.M., Natcheva, R., Noskova, M., Payne, R.J., Pilkington, K., Robinson, S., Robroek, B.J.M., Rochefort, L., Singer, D., Stenøien, H.K., Tuittila, E.-S., Vellak, K., Verheyden, A., Waddington, J.M. \& Rice, S.K. (2018) Environmental and taxonomic controls of carbon and oxygen stable isotope composition in Sphagnum across broad climatic and geographic ranges. Biogeosciences 15 (16): 5189-5202.

https://doi.org/10.5194/bg-15-5189-2018

Greenwood, J.L. \& Stark, L.R. (2014) The rate of drying determines the extent of desiccation tolerance in Physcomitrella patens. Functional Plant Biology 41 (5): 460-467. https://doi.org/10.1071/FP13257

Haberlandt, G. (1886) Beiträge zur Anatomie und Physiologie des Laubmoose. Jahrbücher für wissenschaftliche Botanik 17: 359-492.

Haig, D. (2013) Filial mistletoes: the functional morphology of moss sporophytes. Annals of Botany 111: 337-345. https://doi.org/10.1093/aob/mcs295

Haines, W.P. \& Renwick, J.A.A. (2009) Bryophytes as food: comparative consumption and utilization of mosses by a generalist insect herbivore. Entomologia experimentalis et applicata 133 (3): 296-306. https://doi.org/10.1111/j.1570-7458.2009.00929.x 
Hájek, T. \& Beckett, R.P. (2008) Effect of water content components on desiccation and recovery in Sphagnum mosses. Annals of botany 101: $165-173$. https://doi.org/10.1093/aob/mcm287

Hanson, D.T. \& Rice S.K. (Eds.) (2014) Photosynthesis in Bryophytes and Early Land Plants. Springer Netherlands, Dordrecht. https://doi.org/10.1007/978-94-007-6988-5

Hébant, C. (1968) L'évolution des tissus conducteurs chez les Mousses s.str. (Bryopsida). Cryptogamie, Bryologie, Lichénologie 36: $111-113$.

Hébant, C. (1973) Diversity of structure in the water-conducting elements in liverworts and mosses. Journal of the Hattori Botanical Laboratory 37: 229-234.

Hébant, C. (1977) The Conducting Tissues of Bryophytes. J. Cramer. Vaduz.

Hedderson, T.A. \& Longton R.E. (1995) Patterns of life history variation in the Funariales, Polytrichales and Pottiales. Journal of Bryology 18: 639-675. https://doi.org/10.1179/jbr.1995.18.4.639

Hedderson, T.A. \& Longton R.E. (1996) Life History Variation in Mosses: Water Relations, Size and Phylogeny. Oikos 77: 31-43. https://doi.org/10.2307/3545582

Hedderson, T.A. \& Longton, R.E. (2008) Local adaptation in moss life histories: population-level variation and a reciprocal transplant experiment. Journal of Bryology 30: 1-11. https://doi.org/10.1179/174328208X282175

Hedenäs, L. (2002) Important Complexes of Intercorrelated Character States in Pleurocarpous Mosses. Lindbergia 27: $104-121$. https://doi.org/10.1639/0007-2745(2001)104[0072:EFPACS]2.0.CO;2

Hedenäs, L. (2012) Morphological and anatomical features associated with epiphytism among the pleurocarpous mosses-one basis for further research on adaptations and their evolution. Journal of Bryology 34: 79-100. https://doi.org/10.1179/1743282011Y.0000000049

Henriques, D.S.G., Ah-Peng, C. \& Gabriel, R. (2017) Structure and Applications of BRYOTRAIT-AZO, a Trait Database for Azorean Bryophytes. Cryptogamie, Bryologie 38: 137-152.

https://doi.org/10.7872/cryb/v38.iss2.2017.137

Hess, S., Frahm, J.-P. \& Theisen, I. (2005) Evidence of Zoophagy in a Second Liverwort Species, Pleurozia purpurea. The Bryologist 108 (2): 212-218. https://doi.org/10.1639/6

Jean, M., Holland-Moritz, H., Melvin, A.M., Johnstone, J.F. \& Mack, M.C. (2020) Experimental assessment of tree canopy and leaf litter controls on the microbiome and nitrogen fixation rates of two boreal mosses. New Phytologist 5: 1335-1349. https://doi.org/10.1111/nph.16611

Johansson, V., Lönnell, N., Sundberg, S. \& Hylander, K. (2014) Release thresholds for moss spores: the importance of turbulence and sporophyte length. Journal of Ecology 102: 721-729. https://doi.org/10.1111/1365-2745.12245

Kirbis, A., Waller, M., Ricca, M., Bont, Z., Neubauer, A., Goffinet, B. \& Szövényi, P. (2020) Transcriptional Landscapes of Divergent Sporophyte Development in Two Mosses, Physcomitrium (Physcomitrella) patens and Funaria hygrometrica. Frontiers in Plant Science 11: 747. https://doi.org/10.3389/fpls.2020.00747

Kolari, P., Pumpanen, J., Kulmala, L., Ilvesniemi, H., Nikinmaa, E., Grönholm, T. \& Hari, P. (2006) Forest floor vegetation plays an important role in photosynthetic production of boreal forests. Forest Ecology and Management 221: 241-248. https://doi.org/10.1016/j.foreco.2005.10.021

Kostka, J.E., Weston, D.J., Glass, J.B., Lilleskov, E.A., Shaw, A.J. \& Turetsky, M.R. (2016) The Sphagnum microbiome: new insights from an ancient plant lineage. New Phytologist 211: 57-64. https://doi.org/10.1111/nph.13993

Laaka-Lindberg, S., Korpelainen, H. \& Pohjamo, M. (2003) Dispersal of asexual propagules in bryophytes. Journal of the Hattori Botanical Laboratory 93: 319-330.

Laenen, B., Shaw, B., Schneider, H., Goffinet, B., Paradis, E., Désamoré, A., Heinrichs, J., Villarreal, J.C., Gradstein, S.R., McDaniel, S.F., Long, D.G., Forrest, L.L., Hollingsworth, M.L., Crandall-Stotler, B., Davis, E.C., Engel, J., Von Konrat, M., Cooper, E.D., Patiño, J., Cox, C.J., Vanderpoorten, A. \& Shaw, A.J. (2014) Extant diversity of bryophytes emerged from successive post-Mesozoic diversification bursts. Nature Communications 5: 5134. https://doi.org/10.1038/ncomms6134

Lavorel, S. \& Garnier, E. (2002) Predicting changes in community composition and ecosystem functioning from plant traits: revisiting the Holy Grail. Functional Ecology 16: 545-556. 
https://doi.org/10.1046/j.1365-2435.2002.00664.x

Lenton, T.M., Dahl, T.W., Daines, S.J., Mills, B.J.W., Ozaki, K., Saltzman, M.R. \& Porada, P. (2016) Earliest land plants created modern levels of atmospheric oxygen. Proceedings of the National Academy of Sciences 113: 9704-9709.

https://doi.org/10.1073/pnas.1604787113

Li, F.-W., Nishiyama, T., Waller, M., Frangedakis, E., Keller, J., Li, Z., Fernandez-Pozo, N., Barker, M.S., Bennett, T., Blázquez, M.A, Cheng, S.-F., Cuming, A.C., de Vries, J., de Vries, S., Delaux, P.-M., Diop, I.S., Harrison, C.J., Hauser, D., Hernández-García, J., Kirbis, A., Meeks, J.C., Monte, I., Mutte, S.K., Neubauer, A., Quandt, D., Robison, T., Shimamura, M., Rensing, S.A., Villarreal, J.C., Weijers, D., Wicke, S., Wong, G.K.-S., Sakakibara, K. \& Szövényi, P. (2020) Anthoceros genomes illuminate the origin of land plants and the unique biology of hornworts. Nature Plants 6: 259-272.

https://doi.org/10.1038/s41477-020-0618-2

Ligrone, R., Duckett, J.G. \& Renzaglia, K.S. (2000) Conducting tissues and phyletic relationships of bryophytes. Philosophical Transactions of the Royal Society B: Biological Sciences 355: 795-813.

https://doi.org/10.1098/rstb.2000.0616

Ligrone, R., Duckett, J.G. \& Renzaglia, K.S. (2012) Major transitions in the evolution of early land plants: a bryological perspective. Annals of Botany 109: 851-871.

https://doi.org/10.1093/aob/mcs017

Lindo, Z. \& Gonzalez, A. (2010) The bryosphere: an integral and influential component of the Earth's biosphere. Ecosystems 13: 612627.

https://doi.org/10.1007/s10021-010-9336-3

Löbel, S., Mair, L., Lönnell, N., Schröder, B. \& Snäll, T. (2018) Biological traits explain bryophyte species distributions and responses to forest fragmentation and climatic variation. Journal of Ecology 106: 1700-1713.

https://doi.org/10.1111/1365-2745.12930

Löbel, S. \& Rydin, H. (2010) Trade-offs and habitat constraints in the establishment of epiphytic bryophytes: Trade-offs and habitat constraints. Functional Ecology 24: 887-897.

https://doi.org/10.1111/j.1365-2435.2010.01705.x

Longton, R.E. (1988). Biology of polar bryophytes and lichens. CUP Archive. https://doi.org/10.1017/CBO9780511565212

Maciel-Silva, A.S., Coelho, M.L.P. \& Pôrto, K.C. (2013) Reproductive traits in the tropical moss Octoblepharum albidum Hedw. differ between rainforest and coastal sites. Journal of Bryology 35: 206-215.

https://doi.org/10.1179/1743282013Y.0000000059

Mägdefrau, C. (1935) Untersuchungen über die Wasserversorgung des Gametophyten und Sporophyten des Laubmoose. Zeitschrift fúr Botanik 29: 337-375.

Mallen-Cooper, M. \& Cornwell, W.K. (2020) A systematic review of transplant experiments in lichens and bryophytes. The Bryologist 123: 444-454.

https://doi.org/10.1639/0007-2745-123.3.443

Manyanga, P., Söderström, L. \& Hedderson T.A. (2011) Co-variation of life history characters in the family Lophoziaceae: a multivariate analysis. The Bryologist 114: 583-594.

https://doi.org/10.1639/0007-2745-114.3.583

Marks, R.A., Burton, J.F. \& McLetchie, D.N. (2016) Sex differences and plasticity in dehydration tolerance: insight from a tropical liverwort. Annals of Botany 118: 347-356. https://doi.org/10.1093/aob/mcw102

Marks, R.A., Pike, B.D. \& McLetchie, D.N. (2019a) Water stress tolerance tracks environmental exposure and exhibits a fluctuating sexual dimorphism in a tropical liverwort. Oecologia 191: 791-802. https://doi.org/10.1007/s00442-019-04538-2

Marks, R.A., Smith, J.J., Cronk, Q., Grassa, C.J. \& McLetchie, D.N. (2019b) Genome of the tropical plant Marchantia inflexa : implications for sex chromosome evolution and dehydration tolerance. Scientific Reports 9: 8722. https://doi.org/10.1038/s41598-019-45039-9

Martin, K. \& Hik, D. (1992) Willow Ptarmigan Chicks Consume Moss Sporophyte Capsules (Polluelos de Lagopus lagopus Consumen Cápsulas de Esporofitos de Musgos). Journal of Field Ornithology 63: 355-358.

Mazziotta, A., Granath, G., Rydin, H., Bengtsson, F. \& Norberg, J. (2019) Scaling functional traits to ecosystem processes: Towards a mechanistic understanding in peat mosses. Journal of Ecology 107: 843-859.

https://doi.org/10.1111/1365-2745.13110

McDaniel, S.F. (2018) The Genetic Basis of Natural Variation in Bryophyte Model Systems. Annual Plant Reviews Online 36: 16-41. https://doi.org/10.1002/9781119312994.apr0385 
Mishler, B.D. (2001) The biology of bryophytes-bryophytes aren’t just small tracheophytes. American Journal of Botany 88 (11): 2129 2131. https://doi.org/10.2307/3558438

Moore, J.D., Kollar, L.M. \& McLetchie, D.N. (2016) Does selection for gamete dispersal and capture lead to a sex difference in clump water-holding capacity? American Journal of Botany 103: 1449-1457. https://doi.org/10.3732/ajb.1600096

Moore, P.A., Smolarz, A.G., Markle, C.E. \& Waddington, J.M. (2019) Hydrological and Thermal Properties of Moss and Lichen Species on Rock Barrens: Implications for Turtle Nesting Habitat. Ecohydrology: e2057. https://doi.org/10.1002/eco.2057

Mueller-Dombois, D. \& Boehmer, H.J. (2013) Origin of the Hawaiian rainforest and its transition states in long-term primary succession. Biogeosciences 10: 5171-5182. https://doi.org/10.5194/bg-10-5171-2013

Nelsen, M.P., Lücking, R., Boyce, C.K., Lumbsch, H.T. \& Ree, R.H. (2020) No support for the emergence of lichens prior to the evolution of vascular plants. Geobiology 18: 3-13. https://doi.org/10.1111/gbi.12369

Niinemets, Ü. \&. Tobias M. (2019) Canopy leaf area index at its higher end: dissection of structural controls from leaf to canopy scales in bryophytes. New Phytologist 223: 118-133. https://doi.org/10.1111/nph.15767

Niklas, K.J. \& Spatz, H.C. (2012) Plant physics. University of Chicago Press. https://doi.org/10.7208/chicago/9780226586342.001.0001

Oke, T. \& Turetsky, M.R. (2020) Spatial pattern of intraspecific trait variability in Sphagnum fuscum. Botany 98: 717-723. https://doi.org/10.1139/cjb-2020-0077

Oliver, M.J., Velten, J. \& Wood, A.J. (2000) Bryophytes as experimental models for the study of environmental stress tolerance: Tortula ruralis and desiccation-tolerance in mosses. Plant Ecology 151: 73-84. https://doi.org/10.1023/A:1026598724487

Oliver, M.J., Murdock, A.G., Mishler, B.D., Kuehl, J.V., Boore, J.L., Mandoli, D.F., DE Everett, K., Wolf, P.G., Duffy, A.M. \& Karol, K.G. (2010) Chloroplast genome sequence of the moss Tortula ruralis: gene content, polymorphism, and structural arrangement relative to other green plant chloroplast genomes. BMC genomics 11: 143. https://doi.org/10.1186/1471-2164-11-143

Ortiz-Ramírez, C., Hernandez-Coronado, M., Thamm, A., Catarino, B., Wang, M., Dolan, L., Feijó, J.A. \& Becker, J.D. (2016) A Transcriptome Atlas of Physcomitrella patens Provides Insights into the Evolution and Development of Land Plants. Molecular Plant 9: 205-220. https://doi.org/10.1016/j.molp.2015.12.002

Pan, Z., Pitt, W.G., Zhang, Y., Wu, N., Tao, Y. \& Truscott, T.T. (2016) The upside-down water collection system of Syntrichia caninervis. Nature Plants 2: 1-5. https://doi.org/10.1038/nplants.2016.76

Patiño, J., Bisang, I., Hedenäs, L., Dirkse, G., Bjarnason, Á.H., Ah-Peng, C. \& Vanderpoorten, A. (2013) Baker's law and the island syndromes in bryophytes. Journal of Ecology 101: 1245-1255. https://doi.org/10.1111/1365-2745.12136

Pederson, E.R.A., Warshan, D. \& Rasmussen, U. (2019) Genome Sequencing of Pleurozium schreberi: The Assembled and Annotated Draft Genome of a Pleurocarpous Feather Moss. G3: Genes, Genomes, Genetics 9: 2791-2797. https://doi.org/10.1534/g3.119.400279

Pereira, M.R., Dambros, C. de S. \& Zartman, C.E. (2013) Will the real Syrrhopodon leprieurii please stand up? The influence of topography and distance on phenotypic variation in a widespread Neotropical moss. The Bryologist 116: 58-64. https://doi.org/10.1639/0007-2745-116.1.058

Perera-Castro, A.V., Waterman, M.J., Turnbull, J.D., Ashcroft, M.B., McKinley, E., Watling, J.R., Bramley-Alves, J., Casanova-Katny, A., Zuniga, G., Flexas, J. \& Robinson, S.A. (2020) It Is Hot in the Sun: Antarctic Mosses Have High Temperature Optima for Photosynthesis Despite Cold Climate. Frontiers in Plant Science 11: 1178. https://doi.org/10.3389/fpls.2020.01178

Peters, K., Treutler, H., Döll, S., Kindt, A.S., Hankemeier, T. \& Neumann, S. (2019) Chemical diversity and classification of secondary metabolites in nine bryophyte species. Metabolites 9 (10): 222. https://doi.org/10.3390/metabo9100222

Piatkowski, B.T. \& Shaw, A.J. (2019) Functional trait evolution in Sphagnum peat mosses and its relationship to niche construction. New Phytologist 223: 939-949. 
https://doi.org/10.1111/nph.15825

Pohjamo, M., Laaka-Lindberg, S., Ovaskainen, O. \& Korpelainen, H. (2006) Dispersal potential of spores and asexual propagules in the epixylic hepatic Anastrophyllum hellerianum. Evolutionary Ecology 20: 415-430.

https://doi.org/10.1007/s10682-006-0011-2

Porada, P., Ekici, A. \& Beer, C. (2016) Effects of bryophyte and lichen cover on permafrost soil temperature at large scale. The Cryosphere 10: 2291-2315.

https://doi.org/10.5194/tc-10-2291-2016

Porada, P., Stan, J.T.V. \& Kleidon, A. (2018) Significant contribution of non-vascular vegetation to global rainfall interception. Nature Geoscience 11: 563-567. https://doi.org/10.1038/s41561-018-0176-7

Porada, P., Weber, B., Elbert, W., Pöschl, U. \& Kleidon, A. (2014) Estimating impacts of lichens and bryophytes on global biogeochemical cycles. Global Biogeochemical Cycles 28: 71-85. https://doi.org/10.1002/2013GB004705

Pressel, S., Matcham, H.W. \& Duckett, J.G. (2007) Studies of protonemal morphogenesis in mosses. XI. Bryum and allied genera: a plethora of propagules. Journal of Bryology 29 (4): 241-258. https://doi.org/10.1179/174328207X244042

Pressel, S., Bidartondo, M.I., Ligrone, R. \& Duckett, J.G. (2014) Fungal symbioses in bryophytes: new insights in the twenty first century. Phytotaxa 9 (1): 238-253. https://doi.org/10.11646/phytotaxa.9.1.13

Proctor, M.C. (2000) The bryophyte paradox: tolerance of desiccation, evasion of drought. Plant Ecology 151: 41-49. https://doi.org/10.1023/A:1026517920852

Proctor, M.C., Oliver, M.J., Wood, A.J., Alpert, P., Stark, L.R., Cleavitt, N.L. \& Mishler, B.D. (2007) Desiccation-tolerance in bryophytes: a review. The Bryologist 110: 595-621. https://doi.org/10.1639/0007-2745(2007)110[595:DIBAR]2.0.CO;2

Reed, S.C., Coe, K.K., Sparks, J.P., Housman, D.C., Zelikova, T.J. \& Belnap, J. (2012) Changes to dryland rainfall result in rapid moss mortality and altered soil fertility. Nature Climate Change 2 (10): 752-755. https://doi.org/10.1038/nclimate1596

Renner, M.A. (2015) Lobule shape evolution in Radula (Jungermanniopsida): one rate fits all? Botanical Journal of the Linnean Society 178: $222-242$.

https://doi.org/10.1111/boj.12279

Renzaglia, K.S., Aguilar, J.C.V. \& Garbary, D.J. (2018) Morphology supports the setaphyte hypothesis: mosses plus liverworts form a natural group. Bryophyte Diversity and Evolution 40: 11-17. https://doi.org/10.11646/bde.40.2.1

Renzaglia, K.S., Browning, W.B. \& Merced, A. (2020) With Over 60 Independent Losses, Stomata Are Expendable in Mosses. Frontiers in Plant Science 11: 567. https://doi.org/10.3389/fpls.2020.00567

Rice, S.K. (2012) The cost of capillary integration for bryophyte canopy water and carbon dynamics. Lindbergia 35: 53-62.

Rice, S.K., Aclander, L. \& Hanson, D.T. (2008) Do bryophyte shoot systems function like vascular plant leaves or canopies? Functional trait relationships in Sphagnum mosses (Sphagnaceae). American Journal of Botany 95: 1366-1374. https://doi.org/10.3732/ajb.0800019

Rice, S.K., Gagliardi, T.A. \& Krasa, R.A. (2018) Canopy structure affects temperature distributions and free convection in moss shoot systems. American Journal of Botany 105: 1499-1511. https://doi.org/10.1002/ajb2.1145

Rice, S.K., Neal, N., Mango, J. \& Black, K. (2011) Relationships among shoot tissue, canopy and photosynthetic characteristics in the feathermoss Pleurozium schreberi. The Bryologist 114: 367-378. https://doi.org/10.1639/0007-2745-114.2.367

Rose, J.P., Kriebel, R. \& Sytsma, K.J. (2016) Shape analysis of moss (Bryophyta) sporophytes: Insights into land plant evolution. American Journal of Botany 4: 652-662. https://doi.org/10.3732/ajb.1500394

Rousk, K., Degboe, J., Michelsen, A., Bradley, R. \& Bellenger, J.-P. (2017) Molybdenum and phosphorus limitation of moss-associated nitrogen fixation in boreal ecosystems. New Phytologist 214 (1): 97-107. https://doi.org/10.1111/nph.14331

Russo, N.J., Robertson, M., MacKenzie, R., Goffinet, B. \& Jiménez, J.E. (2020) Evidence of targeted consumption of mosses by birds in sub-Antarctic South America. Austral Ecology 45 (3): 399-403. 
https://doi.org/10.1111/aec.12858

Saiz Val, E. (2020) The effects of increased atmospheric reactive nitrogen deposition upon rates of biological nitrogen fixation in peatlands and temperate forests. Doctoral dissertation, Keele University.

Shaw, A.J., Schmutz, J., Devos, N., Shu, S., Carrell, A.A. \& Weston, D.J. (2016) The Sphagnum Genome Project. In: Advances in Botanical Research. Elsevier, pp. 167-187.

https://doi.org/10.1016/bs.abr.2016.01.003

Sierra, A.M., Toledo, J.J., Allen, N.S. \& Zartman, C.E. (2019) Reproductive traits as predictors of assembly chronosequence patterns in epiphyllous bryophyte metacommunities. Journal of Ecology 107: 875-886. https://doi.org/10.1111/1365-2745.13058

Silva, J.B., Sfair, J.C., dos Santos, N.D. \& Pôrto, K.C. (2018) Different trait arrangements can blur the significance of ecological drivers of community assembly of mosses from rocky outcrops. Flora 238: 43-50. https://doi.org/10.1016/j.flora.2017.02.003

Slate, M.L., Rosenstiel, T.N. \& Eppley, S.M. (2017) Sex-specific morphological and physiological differences in the moss Ceratodon purpureus (Dicranales). Annals of Botany 120: 845-854. https://doi.org/10.1093/aob/mcx071

Slate, M.L., Stark, L.R., Greenwood, J.L., Clark, T.A. \& Brinda, J.C. (2018) The role of prehydration in rescuing shoots of mosses damaged by extreme desiccation events: Syntrichia norvegica (Pottiaceae). The Bryologist 121 (2): 193-204.

https://doi.org/10.1639/0007-2745-121.2.193

Smith, A.J.E. (1982) Bryophyte ecology Springer, Dordrecht. https://doi.org/10.1007/978-94-009-5891-3

Soudzilovskaia, N.A., Graae, B.J., Douma, J.C., Grau, O., Milbau, A., Shevtsova, A., Wolters, L. \& Cornelissen, J.H.C. (2011) How do bryophytes govern generative recruitment of vascular plants? New Phytologist 190: 1019-1031.

https://doi.org/10.1111/j.1469-8137.2011.03644.x

Sousa, F. de, Foster, P.G., Donoghue, P.C.J., Schneider, H. \& Cox, C.J. (2019) Nuclear protein phylogenies support the monophyly of the three bryophyte groups (Bryophyta Schimp.). New Phytologist 222: 565-575. https://doi.org/10.1111/nph.15587

Spitale, D., Mair, P. \& Nascimbene, J. (2020) Patterns of bryophyte life-forms are predictable across land cover types. Ecological Indicators 109: 105799 . https://doi.org/10.1016/j.ecolind.2019.105799

Stanton, D.E., Merlin, M., Bryant, G. \& Ball, M.C. (2014) Water redistribution determines photosynthetic responses to warming and drying in two polar mosses. Functional Plant Biology 41: 178-186.

https://doi.org/10.1071/FP13160

Stark, L.R., Mishler, B.D. \& McLetchie, D.N. (2000) The cost of realized sexual reproduction: assessing patterns of reproductive allocation and sporophyte abortion in a desert moss. American Journal of Botany 87: 1599-1608.

https://doi.org/10.2307/2656736

Stech, M., Kolvoort, E., Loonen, M.J.J.E., Vrieling, K. \& Kruijer, J.D. (2011) Bryophyte DNA sequences from faeces of an arctic herbivore, barnacle goose (Branta leucopsis). Molecular Ecology Resources 11 (2): 404-408. https://doi.org/10.1111/j.1755-0998.2010.02938.x

Suren, A.M. \& Winterbourn, M.J. (1991) Consumption of aquatic bryophytes by alpine stream invertebrates in New Zealand. New Zealand Journal of Marine and Freshwater Research 25 (3): 331-343. https://doi.org/10.1080/00288330.1991.9516487

Szövényi, P. (2016) Chapter Six-The Genome of the Model Species Anthoceros agrestis. In: Rensing, S.A. (Ed.) Advances in Botanical Research, Genomes and Evolution of Charophytes, Bryophytes, Lycophytes and Ferns. Academic Press, pp. 189-211. https://doi.org/10.1016/bs.abr.2015.12.001

Tansley, A.G. \& Chick, E. (1901) Notes on the Conducting Tissue-System in Bryophyta. Annals of Botany 15: 1-38. https://doi.org/10.1093/oxfordjournals.aob.a088805

Tiselius, A.K., Lundbäck, S., Lönnell, N., Jansson, R. \& Dynesius, M. (2019) Bryophyte community assembly on young land uplift islands-Dispersal and habitat filtering assessed using species traits. Journal of Biogeography 46: 2188-2202. https://doi.org/10.1111/jbi.13652

Tuba, Z., Slack, N.G. \& Stark, L.R. (Eds.) (2011) Bryophyte ecology and climate change. Cambridge University Press.

U'Ren, J.M., Lutzoni, F., Miadlikowska, J. \& Arnold, A.E. (2010) Community Analysis Reveals Close Affinities Between Endophytic and Endolichenic Fungi in Mosses and Lichens. Microbial Ecology 60: 340-353. https://doi.org/10.1007/s00248-010-9698-2

U’Ren, J.M., Lutzoni, F., Miadlikowska, J., Zimmerman, N.B., Carbone, I., May, G. \& Arnold, A.E. (2019) Host availability drives 
distributions of fungal endophytes in the imperilled boreal realm. Nature Ecology \& Evolution 3: 1430-1437.

https://doi.org/10.1038/s41559-019-0975-2

Villegas, J.C., Tobón, C. \& Breshears, D.D. (2008) Fog interception by non-vascular epiphytes in tropical montane cloud forests: dependencies on gauge type and meteorological conditions. Hydrological Processes 22: 2484-2492.

https://doi.org/10.1002/hyp.6844

Vilmundardóttir, O.K., Sigurmundsson, F.S., Møller Pedersen, G.B., Belart, J.M.-C., Kizel, F., Falco, N., Benediktsson, J.A. \& Gísladóttir, G. (2018) Of mosses and men: Plant succession, soil development and soil carbon accretion in the sub-Arctic volcanic landscape of Hekla, Iceland. Progress in Physical Geography: Earth and Environment 42: 765-791.

https://doi.org/10.1177/0309133318798754

Voortman, B.R., Bartholomeus, R.P., van Bodegom, P.M., Gooren, H., van der Zee, S.E. \& Witte, J.P.M. (2014) Unsaturated hydraulic properties of xerophilous mosses: towards implementation of moss covered soils in hydrological models. Hydrological Processes 28: $6251-6264$

https://doi.org/10.1002/hyp.10111

Waite, M. \& Sack, L. (2010) How does moss photosynthesis relate to leaf and canopy structure? Trait relationships for 10 Hawaiian species of contrasting light habitats. New Phytologist 185: 156-172.

https://doi.org/10.1111/j.1469-8137.2009.03061.x

Waite, M. \& Sack, L. (2011) Does global stoichiometric theory apply to bryophytes? Tests across an elevation $\times$ soil age ecosystem matrix on Mauna Loa, Hawaii: Does global stoichiometric theory apply to bryophytes? Journal of Ecology 99: 122-134. https://doi.org/10.1111/j.1365-2745.2010.01746.x

Wang, L., Zhao, L., Song, X., Wang, Q., Kou, J., Jiang, Y. \& Shao, X.-M. (2019) Morphological traits of Bryum argenteum and its response to environmental variation in arid and semi-arid areas of Tibet. Ecological Engineering 136: 101-107. https://doi.org/10.1016/j.ecoleng.2019.06.013

Wang, Z. \& Bader, M.Y. (2018) Associations between shoot-level water relations and photosynthetic responses to water and light in 12 moss species. AoB PLANTS 10: ply034. https://doi.org/10.1093/aobpla/ply034

Wang, Z., Bao, W., Feng, D. \& Lin, H. (2014) Functional trait scaling relationships across 13 temperate mosses growing in wintertime. Ecological Research 29: 629-639. https://doi.org/10.1007/s11284-014-1146-1

Wang, Z., Bader, M.Y., Liu, X., Zhu, Z. \& Bao, W. (2017a) Comparisons of photosynthesis-related traits of 27 abundant or subordinate bryophyte species in a subalpine old-growth fir forest. Ecology and Evolution 7: 7454-7461. https://doi.org/10.1002/ece3.3277

Wang, Z., Liu, X., Bader, M.Y., Feng, D. \& Bao, W. (2017b) The 'plant economic spectrum' in bryophytes, a comparative study in subalpine forest. American Journal of Botany 104: 261-270.

https://doi.org/10.3732/ajb.1600335

Wright, I.J., Reich, P.B., Westoby, M., Ackerly, D.D., Baruch, Z., Bongers, F., Cavender-Bares, , J., Chapin, T., Cornelissen, J.H.C., Diemer, M., Flexas, J., Garnier, E., Groom, P.K., Gulias, J., Hikosaka, K., Lamont, B.B., Lee, T., Lee, W., Lusk, C., Midgley, J.J., Navas, M.L., Niinemets, Ü., Oleksyn, J., Osada, N., Poorter, H., Poot, P., Prior, L., Pyankov, V.I., Roumet, C., Thomas, S.C., Tjoelker, M.G., Veneklaas, E.J. \& Villar, R. (2004) The worldwide leaf economics spectrum. Nature 428: 821-827. https://doi.org/10.1038/nature02403

Wu, N., Zhang, Y., Downing, A., Aanderud, Z.T., Tao, Y. \& Williams, S. (2014) Rapid adjustment of leaf angle explains how the desert moss, Syntrichia caninervis, copes with multiple resource limitations during rehydration. Functional Plant Biology 41: 168-177. https://doi.org/10.1071/FP13054

Xiao, B. \& Bowker, M.A. (2020) Moss-biocrusts strongly decrease soil surface albedo, altering land-surface energy balance in a dryland ecosystem. Science of The Total Environment 741: 140425 https://doi.org/10.1016/j.scitotenv.2020.140425

Xiao, B., Sun, F., Yao, X., Hu, K. \& Kidron, G.J. (2019) Seasonal variations in infiltrability of moss-dominated biocrusts on aeolian sand and loess soil in the Chinese Loess Plateau. Hydrological Processes 33: 2449-2463. https://doi.org/10.1002/hyp.13484

Zanatta, F., Patiño, J., Lebeau, F., Massinon, M., Hylander, K., de Haan, M., Ballings, P., Degreef, J. \& Vanderpoorten, A. (2016) Measuring spore settling velocity for an improved assessment of dispersal rates in mosses. Annals of Botany 118: 197-206. https://doi.org/10.1093/aob/mcw092

Zhang, J., Fu, X.-X., Li, R.-Q., Zhao, X., Liu, Y., Li, M.-H., Zwaenepoel, A., Ma, H., Goffinet, B., Guan, Y.-L., Xue, J.-Y., Wang, Q.-F., Wang, Q.-H., Wang, J.-Y., Zhang, G.-Q., Wang, Z.-W., Jia, Y., Wang, M.-Z., Dong, S.-S., Yang, J.-F., Jiao, Y.-N., Guo, Y.-L., Kong, H.-Z., Lu, A.-M., Yang, H.-M., Zhang, S.-Z., Van de Peer, Y., Liu, Z.-J. \& Chen, Z.-D. (2020) The hornwort genome and early land 
plant evolution. Nature Plants 6: 107-118.

https://doi.org/10.1038/s41477-019-0588-4

Zotz, G. \& Kahler, H. (2007) A moss “canopy"-Small-scale differences in microclimate and physiological traits in Tortula ruralis. Flora 202: 661-666.

https://doi.org/10.1016/j.flora.2007.05.002

Zuijlen, K. van, Roos, R.E., Klanderud, K., Lang, S.I., Wardle, D.A. \& Asplund, J. (2020) Decomposability of lichens and bryophytes from across an elevational gradient under standardized conditions. Oikos 129: 1358-1368.

https://doi.org/10.1111/oik.07257 